\title{
Petrol consumption towards unsustainable development: Iranian case study
}

\author{
S. B. Imandoust \\ Payam Noor University, Iran
}

\begin{abstract}
One of the most important economic problems in Iran is petrol consumption. In fact, one litre of petrol in Iran is cheaper than one bottle of drinking water. Every year the government pays a large sum of money for imported petrol as well as petrol subsidies. Thus people consume it in an inefficient manner and petrol smuggling is a very popular job especially near boundaries. In the current Iranian year (21 ${ }^{\text {st }}$ March 2006-20th March 2007) about seventy million litres of petrol were consumed daily in Iran (the biggest petrol importer in the Middle East). This research reports the trend of petrol consumption during the last two decades and studies different scenarios for making decisions about petrol pricing and consumption. Finally some suggestions are presented for correcting the petrol consumption pattern.
\end{abstract}

Keywords: petrol consumption, unsustainable development, petrol pricing.

\section{Introduction}

One of the most important threats against sustainable development in Iran is energy subsidies. About $17.5 \%$ of GDP (gross domestic production) is allocated to energy subsidies every year. More than $25 \%$ of GDP is allocated to total subsidies in Iranian economics. The petrol price in Iran is about 9 cents per litre, so people consume it in a uneconomic manner. Official data shows during the last five years petrol consumption increased $10 \%$ yearly. In the current year about 70 million litres have been consumed daily by Iranians [1]. From the environmental point of view this level of petrol consumption caused high levels of air pollution especially in big cities and because of that Tehran (capital of Iran) is one of the most air polluted cities in the world. Because of its cheap price smugglers have high motivation for petrol smuggling. Although Iran is the fourth 
biggest petroleum producer in the world it simultaneously imports petrol from abroad. For example in the financial year 2006-07 about 4 billion US dollars of petrol was imported by the Iranian government, in other words Iran is the biggest petrol importer in the Middle East. Among 12 Middle East countries, 31\% of energy production is consumed in Iran. In fact, all refinery production has the lowest price in Iran compared to other countries. Figure 1 demonstrates the trend of daily petrol consumption in Iran during the last 30 years [2].

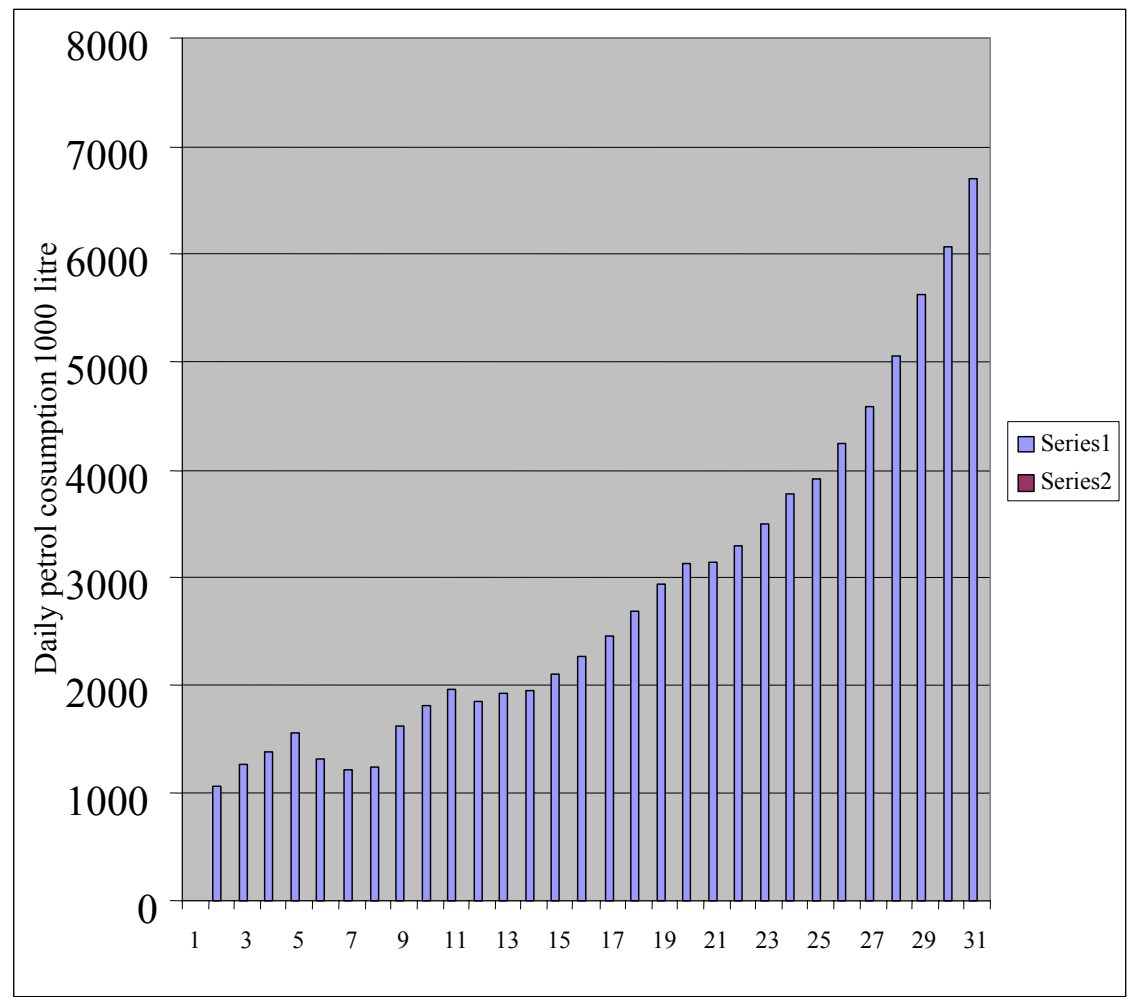

Figure 1: $\quad$ Petrol consumption trend 1976-2006.

Figure 1 shows about seventy million litres of petrol have been burnt per day during the year 2006, it means during 30 years the petrol consumption increased by a factor of seven (1976-2006). At the beginning months of 2007 petrol consumption was beyond seventy million litres per day (unofficial announcement).

\section{Petrol consumption in the OPEC countries}

Petrol is one of the most important refined products in the world and about $98 \%$ of it is consumed in the transport sector. Because of economic and population growth during the last decade petrol consumption has rapidly increased among 
OPEC countries. Table 1 demonstrates petrol consumption during 1999-2005 (1000 barrels per day). Although Indonesia and Nigeria have more population than Iran (218 and 132 million) the Iranian people's consumption is the biggest amount among other OPEC members [3].

Table 1: Petrol consumption in OPEC countries (1000 b/d), 1999-2005.

\begin{tabular}{|c|c|c|c|c|c|c|c|c|}
\hline & 1999 & 2000 & 2001 & 2002 & 2003 & 2004 & 2005 & $\begin{array}{c}\text { \% } \\
\text { Change } \\
05 / 04\end{array}$ \\
\hline ALGERIA & 43.1 & 42.3 & 41.3 & 41.0 & 40.0 & 41.3 & 47.2 & 14.2 \\
\hline INDONESIA & 198.8 & 213.6 & 220.8 & 235.5 & 252.0 & 282.1 & 300.8 & 6.6 \\
\hline IRAN & 213.2 & 225.0 & 256.8 & 298.1 & 336.1 & 375.3 & 413.5 & 10.2 \\
\hline IRAQ & 69.1 & 77.2 & 83.4 & 84.8 & 68.9 & 78.8 & 80.6 & 2.4 \\
\hline KUWAIT & 39.4 & 36.3 & 40.3 & 42.3 & 44.0 & 46.7 & 49.1 & 5.2 \\
\hline LIBYAN & 38.2 & 42.2 & 42.4 & 45.5 & 46.6 & 49.6 & 54.1 & 9.1 \\
\hline NIGERIA & 85.2 & 105.7 & 127.8 & 134.9 & 136.6 & 146.1 & 164.3 & 12.5 \\
\hline QATAR & 11.0 & 11.7 & 12.5 & 15.8 & 13.4 & 14.3 & 16.7 & 17.3 \\
\hline $\begin{array}{l}\text { SAUDI } \\
\text { ARABIA }\end{array}$ & 269.8 & 273.3 & 282.3 & 301.2 & 311.2 & 330.7 & 350.3 & 5.9 \\
\hline $\begin{array}{l}\text { UNITED } \\
\text { ARAB } \\
\text { EMIRATES }\end{array}$ & 37.3 & 45.5 & 55.5 & 65.8 & 72.5 & 72.0 & 75.3 & 4.5 \\
\hline VENEZUELA & 219.5 & 239.2 & 245.8 & 234.5 & 222.9 & 232.4 & 240.1 & 3.3 \\
\hline
\end{tabular}

Source: OPEC annual statistics.

Table 1 shows a $10 \%$ increase in 2004-05 for Iran. Among different areas in the world, North America, with $45.4 \%$ is the biggest and Africa with $2.7 \%$ has the smallest share for petrol consumption.

Nowadays the share of petrol consumption in North America has decreased because of high economic growth in China and India.

\section{Previous research about petrol consumption}

Fortunately I have found precise scientific research about the economic aspects of petrol in Iran that has been carried out by academic persons but unfortunately the governmental officials did not pay attention to these efforts properly. It seems uneconomic considerations have played a first role in this issue. One of the best studies has been done by Khataie [4]; he estimated demand and elasticity of petrol from the period of 1981-2003 and forecast the future of petrol 
consumption using the ARDL (Autoregressive distributed lag modelling approach). As the basis of his study the petrol demand model was introduced as follows:

$$
C G=f(R P G, P O P, T K, Y, A)
$$

$\mathrm{CG}=$ total demand of petrol

$\mathrm{RPG}=$ real price of petrol

$\mathrm{POP}=$ population

$\mathrm{TK}=$ number of cars

$\mathrm{Y}=$ national income

$\mathrm{A}=$ average life of car in Iran

$$
\frac{d C G}{d P O P} \geq 0 \quad \frac{d C G}{d Y} \geq 0 \frac{d C G}{d A} \geq 0 \frac{d C G}{d R P G} \leq 0 \frac{d C G}{d T K} \geq 0
$$

Thus for the period 1981-2003 with the use of the ARDL approach the demand equation is estimated as follows:

$$
\mathrm{CG}=11085-18.5 \mathrm{RPG}+0.0056 \mathrm{TK}-6037 \mathrm{D} 84
$$

D84 is a dummy variable and demonstrates a decrease of oil income in the year 1984. Because the other parameters were not significant the researcher deleted them. As the equation shows there is a weak negative relationship between real petrol price and total petrol demand. Thus, if the government increase the petrol price the demand level will not change drastically. But the number of cars affects the petrol consumption positively.

Abounoori [5] utilised a logarithmic function for estimating the petrol demand function with a OLS (ordinary least squares) approach. He estimated the following equation:

$$
\text { Log Clit }=9.37+.0575 \log \text { Veh }+.0188 \log \mathrm{NI}-0.121 \log \mathrm{PP}+0.851 \log \text { POP }
$$

where

Clit=petrol consumption

Veh $=$ number of vehicle

$\mathrm{NI}=$ national income

$\mathrm{PP}=$ real petrol income

$\mathrm{POP}=$ population

From an economical aspect in this equation the parameters are elasticity coefficients. So we can conclude that petrol demand has a low sensitivity ratio with price. Thus, if government raise prices people will not change their demand significantly. This is because of a lack of appropriate public transport in big cities. 
Moreover every year one million new cars are added to previous cars with a high average of consumption, most of the cars in Iran have four cylinders and burn more than ten litres of petrol per kilometre.

In Iran only a few companies produce cars and all of them belong to the government so no competition exists; they have been supported by the government during the last two decades. They have provided low quality cars with high average petrol consumption and people have to buy their products. Although petrol is cheaper than in other countries, the car is more expensive.

Figure 2 compares real and nominal petrol prices in Iran during 1967-2006.

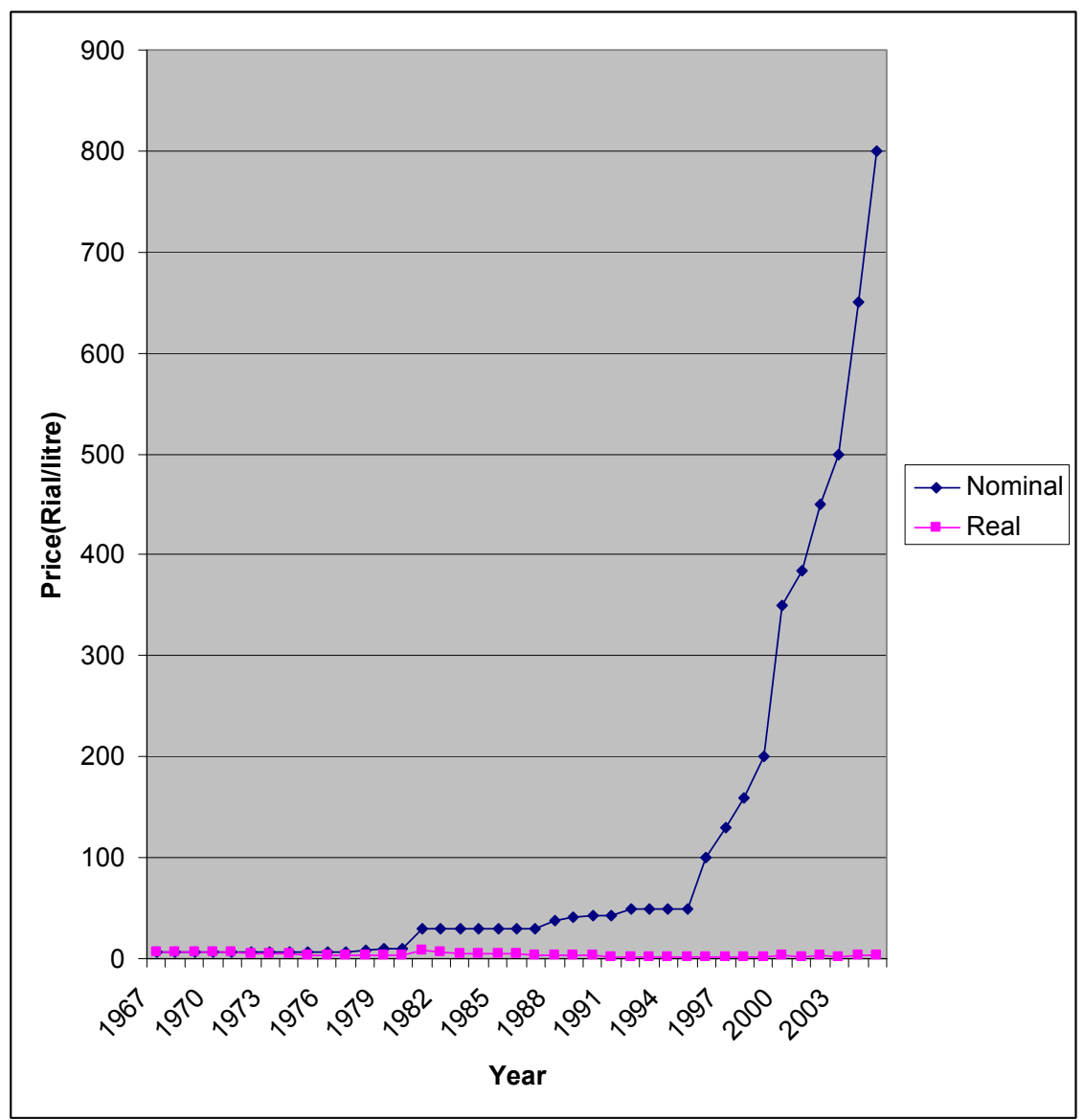

Figure 2: $\quad$ Real and nominal petrol prices (Rial/litre) 1967-2006 [6].

I should mention here because of structural inflation in the Iranian economic system, we have a big gap between real and nominal petrol prices. As can be seen in figure 2 the real petrol price has not varied very much but simultaneously 
the nominal price in most years has risen drastically. The vertical axis presents the price of petrol in Iranian currency (Rial) per litre (9300Rials=1\$). In fact in recent years the real price has decreased although the variation is small. If we compare figures 1 and 2 we can easily conclude that the nominal price and petrol consumption move in the same way, thus we can say petrol is an inelastic commodity in Iran.

\section{Different scenario for petrol pricing}

Nowadays petrol pricing is the most critical issue that the Iranian government and parliament are facing. After long discussions between government officials no clear results have emerged about petrol price. In fact most economists and some parliament members believe that the price should be modified slowly until arriving at the real world price. But the government officials reject that and argue about the inflationary effect of this policy. In the next part of the paper a different manner that can be considered will be noticed.

\subsection{First scenario: continuing of present situation}

This means petrol should be imported and distributed without efficient management and at the present 9 cents per litre. Naturally if we follow this policy inefficient consumption, smuggling, air pollution, traffic jams, no motivation for producing low average car... will go on. Yet people remain happy and enjoy the cheap price.

\subsection{Second scenario: rising price}

As it was proven by previous researches as well as in figures 1 and 2, with the increase of price, demand will not decrease significantly unless price increases drastically. This causes high inflation and decrease of car demand so unemployment also increases. On the other side petrol consumption, smuggling, air pollution will be reduced.

\subsection{Third scenario: quota system for internal production and world price for imported petrol}

If we can separate high income consumers and low income consumers, this policy works otherwise the price gap will create artificial profit.

On the other side, most of the old and high average cars belong to low income people. So this policy affects them and an unjust distribution will arise. But it reduces consumption, smuggling and simultaneously creates motivation for low average car, regulating car engines.

\subsection{Fourth scenario: quota system for internal production without import}

Data shows the average petrol production in nine refineries is about 43 million litres daily. This amount of production can be enough only if private cars use 2.5 
and public cars 25 litres per day. Simultaneously public cars should use CNG as a fuel so double-burn cars should substitute the old cars as well as taxis.

This policy reduces petrol consumption and air pollution but most probably black market for petrol will appear.

\subsection{Distribution of wise card for efficient management}

Recently a wise card has been sent to car owners throughout the country, they help to control consumption and calculate real data. Although many experts are doubtful of this approach the policy has not started practically. Many people announced that they had not received their wise card and nobody knows what will happen in the future. Will this policy work or not? Time itself will show us the truth.

\section{Conclusion}

The trend of petrol consumption in Iran pushes the country towards unsustainable development. More than 70 million litres of petrol have been burnt daily and have caused air pollution, traffic jams, wasting time and money, eye and lung diseases. Moreover a big share of the national income is allocated to imported petrol from abroad.

On account of official data during the last two decades, the nominal price is always raised but consumption also had the same situation. Different factors made this situation, for example lack of easy and efficient public transportation, population growth, existence of old and high average cars and cheap petrol price.

For improving this situation many efforts should be considered. First petrol price should approach the real world price. Second public transportation should be constructed and expanded as soon as possible. Driving and producing the old and high average cars should be banned. Finally if we expand electronic services via the internet for bill payments, shopping, registration etc, this affects traffic as well as petrol consumption.

\section{References}

[1] Moradi, H., Petrol price modification. Economic Development Monthly (Farsi), 10, pp.6-8, 2007.

[2] Petroleum ministry of Iran, Iranian national company of refinery products distribution, statistics office, 2006.

[3] OPEC, www.opec.org

[4] Khataie. M, Analyze of elasticity and demand of petrol in Iran, Iranian Economic Research Quarterly (Farsi), 25, pp. 23-46, 2006.

[5] Abounoori, A., Estimation of petrol demand in Iran. Economic Research Journal (Farsi), 28, pp. 205-229, 2006.

[6] Petroleum ministry of Iran, Iranian national company of refinery products distribution, statistics office, 1966-2006. 